\title{
THE INFLUENCE OF ACCOUNTABILITY ON CLEAN-CORRUPTION PERCEPTION IN LOCAL GOVERNMENT
}

\author{
Ahmad Nur Ikhwan ${ }^{1}$ Bambang Subroto ${ }^{2}$ Abdul Ghofar ${ }^{3}$ \\ Email: putunembahman@gmail.com
}

\begin{abstract}
This study aimed to analyze and examine the influence of financial accountability, performance accountability and public services accountability on the clean-corruption perception. The study population was the local government in Indonesia. Sampling technique used is purposive sampling and obtained 104 sample. The approach used in this research is a quantitative with an analysis tool used is multiple regression. The results show financial accountability and public services accountability influencing the clean-corruption perception, whereas performance accountability can't influencing the clean-corruption perception. Hence it can be concluded that by improving the financial accountability and public services accountability can reduce the prevalence of corruption at the local government.
\end{abstract}

Keywords: clean-corruption perception, financial accountability, performance accountability, public services accountability

\begin{abstract}
ABSTRAK
Penelitian ini bertujuan untuk menguji dan menganalisis pengaruh akuntabilitas keuangan, akuntabilitas kinerja dan akuntabilitas pelayanan publik terhadap persepsi bersih korupsi. Populasi penelitian ini adalah pemerintah daerah tingkat Kabupaten dan Kota di Indonesia. Teknik penyampelan yang digunakan adalah purposive sampling dan diperoleh sampel sebanyak 104 Pemerintah Daerah. Pendekatan penelitian yang digunakan adalah penelitian kuantitatif dengan alat analisis yang digunakan adalah regresi berganda. Hasil penelitian menunjukkan akuntabilitas keuangan dan akuntabilitas pelayanan publik berpengaruh terhadap persepsi bersih korupsi, sedangkan akuntabilitas kinerja tidak berpengaruh terhadap persepsi bersih korupsi. Dengan demikian dapat disimpulkan bahwa dengan meningkatkan akuntabilitas keuangan dan akuntabilitas pelayanan publik pada pemerintah daerah dapat menurunkan tingkat kelaziman korupsi di daerah tersebut.
\end{abstract}

Kata Kunci: akuntabilitas keuangan, akuntabilitas kinerja, akuntabilitas pelayanan publik, persepsi bersih korupsi

\section{PENDAHULUAN}

Pemberantasan korupsi saat ini sudah menjadi salah satu prioritas utama bagi seluruh negara-negara di dunia (Klitgaard, Abaroa, \& Parris, 2002:9). Salah satu alasannya adalah korupsi sudah sangat merajalela, sehingga menimbulkan kemarahan yang luar biasa di masyarakat. Korupsi bukan hanya terjadi di tingkat pemerintah pusat, namun sudah sampai ke tingkat pemerintahan di daerah. Korupsi dilakukan oleh Kepala Daerah dan para pejabat daerah yang seharusnya memajukan daerah tersebut. Koruptor telah menguasai sendi-sendi pemerintahan, koruptor saling menutupi dan melindungi, bahkan mereka melakukan korupsi secara berjamaah sehingga seakan-akan terbentuk sebuah kelompok koruptor yang mirip

\footnotetext{
${ }^{1}$ Mahasiswa Program Magister Akuntansi Pasca Sarjana FEB Universitas Brawijaya

${ }^{2}$ Dosen Fakultas Ekonomi dan Bisnis Universitas Brawijaya

${ }^{3}$ Dosen Fakultas Ekonomi dan Bisnis Universitas Brawijaya
} 
dengan kelompok sindikat penjahat mafia. Alasan utama kenapa korupsi bisa begitu merajalela adalah perkembangan ekonomi dan komunikasi yang begitu cepat, menyebabkan banyak orang yang tergoda perolehan harta kekayaan yang lebih besar secara cepat (Klitgaard et al., 2002:9).

Berbagai upaya telah dilakukan dalam rangka memberantas korupsi di Indonesia. Sebelum era reformasi, pemberantasan korupsi yang lebih dititikberatkan pada cara-cara tradisional seperti memperberat hukuman bagi pelaku korupsi dan memperbanyak sumber daya pengawas, tidak membuahkan hasil yang memuaskan. Memasuki era reformasi, upaya pemberantasan korupsi bukan hanya menitikberatkan pada cara-cara tradisional. Pemberantasan korupsi pasca era reformasi lebih diarahkan untuk mengurangi monopoli dan wewenang serta meningkatkan akuntabilitas. Negara memang mempertegas upaya pemberantasan korupsi melalui diterbitkannya undang-undang nomor 31 tahun 1999 yang diperbarui dengan undang-undang nomor 20 tahun 2001 tentang Pemberantasan Tindak Pidana Korupsi serta dengan membentuk badan independen pemberantasan korupsi melalui undang-undang nomor 30 tahun 2002 tentang Komisi Pemberantasan Tindak Pidana Korupsi, namun juga negara memperkuat upaya pemberantasan korupsi melalui upaya revitalisasi administrasi negara atau yang lebih dikenal dengan istilah reformasi birokrasi. Reformasi birokrasi yang dilakukan oleh pemerintah menjadi bagian dari upaya untuk memperkuat negara termasuk didalamnya adalah pemberantasan korupsi. Dengan reformasi birokrasi, peran dan lingkup intervensi negara (pemerintah) didefinisikan ulang untuk menjawab tantangan zaman dengan cara menyederhanakan struktur birokrasi serta mengubah pola pikir (mindset) dan pola budaya (cultural set) birokrasi dalam tata kelola pemerintahan (Mariana, Paskarina, \& Nurasa, 2010:3).

Langkah penting dalam pemberantasan korupsi adalah dengan memperkuat akuntabilitas pada instansi-instansi pemerintah termasuk pemerintah daerah. Melalui Instruksi Presiden (Inpres) nomor 7 Tahun 1999 tentang Akuntabilitas Kinerja Instansi Pemerintah, instansi-instansi pemerintah termasuk pemerintah daerah diwajibkan untuk melaporkan aktivitasnya dalam pelaksanaan pemerintahan. Dalam Inpres tersebut dijelaskan bahwa akuntabilitas kinerja adalah perwujudan kewajiban suatu instansi pemerintah untuk mempertanggungjawabkan keberhasilan/kegagalan pelaksanaan misi organisasi dalam mencapai tujuan dan sasaran yang ditetapkan melalui alat pertanggungjawaban periodik. Akuntabilitas kinerja bagi instansi pemerintah sangat diperlukan dalam rangka meningkatkan pelaksanaan pemerintahan yang berdaya guna, berhasil guna, bersih dan bertanggungjawab. Termasuk apakah kinerja pemerintah telah ekonomis, efisien dan efektif dalam mencapai visi, misi dan tujuan organisasinya.

Selanjutnya untuk meningkatkan akuntabilitas keuangan pemerintah, dikeluarkan paket undang-undang keuangan negara yaitu undang-undang nomor 17 Tahun 2003 tentang Keuangan Negara, undang-undang nomor 1 Tahun 2004 tentang Perbendaharaan Negara dan undang-undang nomor 15 Tahun 2004 tentang Pemeriksaan Keuangan Negara. Paket undangundang keuangan negara tersebut merupakan bentuk reformasi di bidang administrasi keuangan negara (Afriyanti, Sabanu, \& Noor, 2015).

Dalam rangka peningkatan akuntabilitas penyelenggaraan pemerintahan di daerah, pemerintah mengeluarkan Peraturan Pemerintah nomor 56 tahun 2001 tentang Pelaporan Penyelenggaraan Pemerintahan Daerah yang diperbarui dengan Peraturan Pemerintah nomor 
3 tahun 2007 tentang Laporan Penyelenggaraan Pemerintahan Daerah Kepada Pemerintah, Laporan Keterangan Pertanggungjawaban Kepala Daerah Kepada Dewan Perwakilan Rakyat Daerah, dan Informasi Laporan Penyelenggaraan Pemerintahan Daerah Kepada Masyarakat. Tujuan dari akuntabilitas penyelenggaraan pemerintahan daerah tersebut adalah untuk mengetahui keberhasilan pemerintah daerah dalam memanfaatkan hak yang diperoleh daerah sesuai dengan capaian keluaran dan hasil yang telah direncanakan, sebagai umpan balik dan rekomendasi bagi daerah untuk mendorong peningkatan kinerja penyelenggaraan pemerintah daerah (Afriyanti et al., 2015).

Dalam menjelaskan fenomena korupsi di pemerintah daerah yang ada di Indonesia, dapat digunakan teori agensi (Bergman \& Lane, 1990; Jain, 2001; Rosalina, 2011; Shah, 2007). Korupsi dapat terjadi karena terdapat jarak yang memisahkan sesuai dengan konsep hubungan antara principal dan agent. Jarak tersebut pada akhirnya menyebabkan kondisi asimetri informasi, yaitu kondisi principal tidak mengetahui sepenuhnya kinerja agent.

Dalam melihat perilaku korupsi dengan teori agensi, masyarakat dan pemerintah pusat dapat diposisikan sebagai principal yang memiliki kepentingan atas kinerja pemerintah daerah yang diposisikan sebagai agent. Jarak antara pemerintah pusat dan masyarakat dengan pemerintah daerah kemudian membuka jalan bagi pemerintah daerah untuk mengambil kebijakan yang cenderung menguntungkan dirinya sendiri. Selanjutnya, karena korupsi terjadi karena adanya masalah keagenan seperti yang dijelaskan sebelumnya, maka jarak antara principal dan agent harus direduksi. Adapun jalan yang bisa ditempuh adalah dengan meningkatkan akuntabilitas pemerintah daerah (Bergman \& Lane, 1990; Leruth \& Paul, 2007; Rosalina, 2011; Shah, 2007).

Beberapa penelitian telah mengungkapkan pengaruh akuntabilitas terhadap korupsi. Seperti diungkapkan oleh Palmer (2000) mengungkapkan pencegahan korupsi dapat dilakukan dengan manajemen pencatatan yang baik dalam rangka mendukung akuntabilitas keuangan. Penelitian yang dilakukan oleh Deininger \& Mpuga (2005) mengungkapkan penekanan akuntabilitas yang dilakukan masyarakat melalui keberanian untuk melaporkan tindakan yang tidak etis di kalangan birokrat dapat menurunkan tingkat korupsi dan juga meningkatkan kualitas pelayanan publik secara signifikan. Hasil penelitian yang dilakukan Shah (2007) mengungkapkan negara dengan tingkat tata kelola pemerintahan yang buruk berakibat pada tingginya korupsi, oleh karena itu untuk mereduksi tingkat korupsi diperlukan tata kelola pemerintahan yang baik. Lebih jauh Shah (2007) mengungkapkan bahwa untuk menciptakan tata kelola pemerintah yang baik adalah dengan cara memperkuat akuntabilitas. Ibietan (2013) mengungkapkan bahwa penjelasan fundamental atas terus berlangsungnya korupsi di suatu negara adalah karena lemahnya akuntabilitas atau ketiadaan akuntabilitas yang dibarengi dengan kewenangan mutlak yang dimiliki oleh penguasa.

Penelitian mengenai pengaruh akuntabilitas terutama akuntabilitas keuangan terhadap korupsi di Indonesia dilakukan oleh Olken (2007) yang melakukan penelitian pada pembangunan jalan desa yang ada di Indonesia, hasil penelitiannya menunjukkan bahwa aktivitas top down monitoring oleh auditor pemerintah yang dalam hal ini dilakukan oleh Badan Pengawasan Keuangan dan Pembangunan (BPKP) memiliki pengaruh signifikan atas tinggi atau rendahnya korupsi pada suatu proyek pembangunan. Hasil penelitian Olken (2007) menyatakan bahwa dengan adanya penekanan terhadap akuntabilitas pengelolaan dana 
pembangunan, akan menurunkan tingkat korupsi yang dilakukan oleh pemerintah kecamatan yang mengelola dana tersebut.

Penelitian lainnya dilakukan oleh Rini \& Sarah (2014) yang meneliti pengaruh akuntabilitas keuangan yang ditinjau dari kualitas pelaporan keuangan pemerintah daerah terhadap tingkat korupsi yang ditinjau dari jumlah Tindak Pidana Korupsi yang ditangani KPK, hasil penelitian menunjukkan terdapat kaitan antara kualitas pelaporan keuangan pemerintah daerah dengan tingkat korupsi. Hasil penelitian serupa diungkapkan oleh Masyitoh, Wardhani dan Setyanigrum (2015) yang meneliti pengaruh opini audit BPK dengan Indeks Persepsi Korupsi di 50 (lima puluh) Kabupaten/Kota di Indonesia periode 2008-2010, hasil penelitian menunjukkan akuntabilitas keuangan berpengaruh negatif terhadap korupsi, yaitu berarti semakin baik tata kelola pemerintahan terutama prinsip akuntabilitas dan transparansi dapat menurunkan potensi korupsi.

Hasil yang berbeda diungkapkan oleh Rosalina (2011) yang meneliti pengaruh akuntabilitas keuangan yang di proxy-kan dengan opini audit Badan Pemeriksa Keuangan atas LKPD terhadap korupsi yang di proxy-kan dengan Indeks Persepsi Korupsi (IPK) yang dirilis oleh Transparency International Indonesia pada 46 (empat puluh enam) Kabupaten/Kota di Indonesia, hasil penelitian menunjukkan akuntabilitas keuangan tidak berpengaruh terhadap korupsi. Hasil serupa diungkapkan oleh Heriningsih \& Marita (2013) yang meneliti pengaruh opini audit BPK dengan Indeks Persepsi Korupsi di 13 (tiga belas) Kabupaten/Kota di pulau Jawa periode 2008-2010, hasil penelitian menunjukkan akuntabilitas keuangan tidak berpengaruh terhadap korupsi.

Dari beberapa penelitian diatas dapat disimpulkan bahwa masih terdapat inkonsistensi hasil penelitian pengaruh akuntabilitas keuangan terhadap korupsi, sehingga terdapat celah penelitian yang coba dipersempit dalam penelitian ini.

Pengaruh akuntabilitas kinerja dan akuntabilitas pelayanan publik terhadap pemberantasan korupsi diantaranya diungkapkan oleh Shah (2007) yang menyatakan salah satu prioritas yang harus dilakukan dalam memberantas korupsi adalah dengan mengukur kinerja pelayanan publik. Shah (2007) menyatakan korupsi lebih sulit dideteksi melalui audit keuangan, namun korupsi lebih mudah dideteksi melalui pengamatan atas kinerja pelayanan publik. Setiap upaya dalam rangka memenuhi Standar Pelayanan Minimal yang ditargetkan akan memaksa lembaga-lembaga pemerintah untuk mengatasi penyebab dan konsekuensi dari korupsi. Peters (2007) mengungkapkan akuntabilitas jangan semata-mata dilihat sebagai cara untuk mengidentifikasi penyimpangan dalam sebuah organisasi. Mekanisme akuntabilitas juga harus dilihat sebagai sarana untuk menilai apa yang telah pemerintah berikan untuk warganya. Akuntabilitas harus dapat memberikan gambaran mengenai program-program yang telah dan akan dilaksanakan oleh pemerintah. Dengan adanya akuntabilitas atas program pemerintah, dapat memberikan gambaran apakah program tersebut telah memberikan manfaat kepada masyarakat, dan jika diketahui bahwa program tersebut ternyata merupakan program yang buruk, maka segera dapat dicari penyebabnya dan dapat diperbaiki. Akuntabilitas atas program pemerintah diyakini lebih dapat mengidentifikasi penyimpangan dan korupsi (Peters, 2007).

Belum banyak penelitian yang meneliti pengaruh akuntabilitas kinerja dan akuntabilitas pelayanan publik terhadap korupsi, hal ini merupakan celah penelitian yang coba dipersempit melalui penelitian ini. 
Berdasarkan latar belakang diatas, maka rumusan masalah penelitian ini adalah (1) Apakah akuntabilitas keuangan berpengaruh terhadap persepsi bersih korupsi? (2) Apakah akuntabilitas kinerja berpengaruh terhadap persepsi bersih korupsi? (3) Apakah akuntabilitas pelayanan publik berpengaruh terhadap persepsi bersih korupsi?

\section{RERANGKA TEORITIS}

\section{Teori Agensi}

Dasar pemikiran teori agensi adalah adanya kontrak yang menghubungkan dua belah pihak, yaitu principal dan agent. Principal sebagai pemilik sumber daya mendelegasikan sebagian wewenangnya kepada agent untuk mengelola sumber daya tersebut dengan harapan agar agent akan bertindak atau melakukan pekerjaan seperti yang dinginkan oleh principal. Namun pada dasarnya semua individu bertindak atas kepentingan mereka sendiri, begitu pula dengan agent. Hal tersebut dapat menimbulkan konflik kepentingan antara principal dan agent. Kepentingan Principal adalah untuk memaksimalkan keuntungan mereka sedangkan agent akan berusaha meningkatkan utilitas pribadinya, sehingga dalam menjalankan fungsinya, agent tidak selalu bertindak/melakukan pekerjaan sesuai dengan keinginan principal. Agent akan cenderung berorientasi pada kesejahteraan pribadi dibandingkan dengan berorientasi pada kesejahteraan principal(Jensen \& Meckling, 1976).

Pemisahan antara principal sebagai pemilik sumber daya dengan agent sebagai pengendali sumber daya mendorong terjadinya asimetri informasi antara keduabelah pihak. Asimetri informasi muncul karena agent mempunyai informasi lebih banyak tentang kinerja aktual, motivasi, dan tujuan daripada principal, sehingga principal mengalami keterbatasan mekanisme pengendalian untuk mengawasi kinerja agent, hal tersebut diperparah dengan perilaku agent yang kurang akuntabel (Mishra, 2004). Asimetri informasi yang ada tersebut memungkinkan agent untuk melakukan tindakan oportunis dalam rangka memenuhi keinginan pribadinya (Shah, 2007).

Penggunaan teori agensi dalam menjelaskan fenomena korupsi di sektor publik sebagaimana diungkapkan Jain (2001) adalah karena model hubungan antara principal dan agent sesuai untuk menggambarkan fenomena korupsi yang disebabkan oleh perilaku oportunis pejabat publik. Pejabat publik sebagai agent diberi amanat untuk mengelola sumber daya yang dimiliki principal. Keputusan dan perilaku oportunis yang diambil oleh pejabat publik sebagai agent dalam mengelola sumber daya yang dipercayakan kepadanya dapat dikategorikan sebagai korupsi. Keputusan dan perilaku oportunis tersebut tentu akan merugikan principal sebagai pemilik sumber daya, karena dengan adanya korupsi maka harapan principal tidak akan tercapai secara maksimal.

Asimetri informasi sebagai akar permasalahan korupsi pejabat publik dapat direduksi melalui akuntabilitas pemerintah dalam menginformasikan dan mempertanggungjawabkan setiap kebijakan yang dilakukannya. Akuntabilitas pemerintah daerah akan mempermudah pemerintah pusat dan masyarakat untuk melakukan evaluasi atas kinerja pejabat publik di daerah tersebut. Pada akhirnya, akuntabilitas menjadi isu penting dalam rangka mereduksi tindakan oportunis pejabat publik, karena lemahnya akuntabilitas dianggap sebagai salah satu sebab utama munculnya korupsi di pemerintahan (Bergman \& Lane, 1990; Leruth \& Paul, 2007; Rosalina, 2011). Dengan demikian diperlukan sebuah sarana akuntabilitas yang ditujukan bagi pemerintah daerah untuk menginformasikan dan mempertanggungjawabkan 
kebijakan yang telah mereka lakukan. Sarana akuntabilitas tersebut juga diharapkan mampu memberikan informasi kepada principal, dalam hal ini pemerintah pusat dan masyarakat, untuk mengevaluasi kinerja pemerintah daerah.

\section{Korupsi}

Korupsi secara harfiah berarti kebusukan, keburukan, kebejatan, ketidakjujuran, dapat disuap, tidak bermoral, penyimpangan dari kesucian (Kemendikbud, 2011:23). Dalam arti luas, korupsi berarti menggunakan jabatan untuk keuntungan pribadi (Klitgaard, et.al. 2002:3; Mishra, 2004; Shleifer \& Vishny, 1993; Svensson, 2005). Jabatan adalah kedudukan yang dipercayakan kepada seseorang. Seseorang yang memegang jabatan diberi wewenang atau kekuasaan untuk bertindak atas nama lembaga, baik lembaga privat maupun lembaga publik.

Lebih jauh Klitgaard (1998:99) dan Klitgaard et al. (2002:29) menyatakan bahwa korupsi berkembang manakala terdapat monopoli kekuasaan yang absolut, kewenangan bertindak yang terlalu luas dan tidak jelas, serta lemahnya akuntabilitas. Korupsi kemungkinan besar dapat ditemukan pada lembaga yang memegang monopoli atas barang atau jasa dan memiliki wewenang untuk memutuskan siapa yang berhak mendapat barang atau jasa itu, serta tidak ada akuntabilitas atas kinerja lembaga tersebut yaitu dalam arti pihak lain tidak dapat mengawasi apa yang dilakukan oleh pihak yang memegang kewenangan tersebut.

\section{Persepsi Bersih Korupsi}

Dalam kaitannya dengan penelitian ini, yang menjadi fokus penelitian korupsi adalah persepsi bersih korupsi atas pelayanan publik di pemerintah daerah. Berdasarkan penelitian yang dilakukan oleh Komisi Pemberantasan Korupsi, pelayan publik di Indonesia saat ini masih rawan terjadi korupsi dalam bentuk penyuapan, pemerasan, ataupun gratifikasi. Penggunaan pelayanan publik sebagai fokus penelitian korupsi karena output dari tugas pokok dan fungsi instansi/lembaga pemerintah adalah layanan yang diberikan kepada masyarakat. Walaupun nilai korupsinya tidak selalu besar, korupsi yang terjadi pada layanan publik akan mempengaruhi citra instansi/lembaga dimata masyarakat (KPK, 2014:2). Penggunaan persepsi bersih korupsi sebagai alat pengukuran tingkat korupsi di Pemerintah Daerah mengacu pada penelitian yang dilakukan oleh Olken (2009). Penggunaan indeks persepsi korupsi juga sering digunakan sebagai indikator keberhasilan upaya pemberantasan korupsi di banyak negara-negara di dunia (TII, 2015:4).

Persepsi bersih korupsi menggambarkan tingkat persepsi masyarakat atas kondisi korupsi di pemerintah daerahnya. Semakin rendah persepsi bersih korupsi menandakan semakin lazim terjadi tindakan-tindakan korupsi pada pemerintah daerah tersebut. Sebaliknya, semakin tinggi persepsi bersih korupsi menandakan semakin tidak lazim terjadi tindakan-tindakan korupsi pada pelayanan publik di daerah tersebut. Persepsi bersih korupsi pada penelitian ini didasarkan pada hasil survei yang oleh lembaga yang independen, kredibel dan terpercaya sehingga hasil dari survei tersebut dapat digunakan sebagai sumber informasi dalam penelitian empiris maupun sebagai bahan dalam pengambilan kebijakan anti korupsi.

\section{Akuntabilitas Pemerintah Daerah}

Secara sederhana, akuntabilitas dapat diartikan sebagai sebuah fungsi dari kapabilitas principal dalam menilai kinerja agent mereka (Gailmard, 2012). Mardiasmo (2002:20) menyatakan akuntabilitas adalah kewajiban agent untuk memberikan pertanggungjawaban, menyajikan, melaporkan dan mengungkapkan segala aktivitas dan kegiatan yang menjadi 
tanggungjawabnya kepada principal yang memiliki hak dan kewenangan untuk meminta pertanggungjawaban tersebut. Dalam konteks organisasi pemerintah, akuntabilitas adalah pemberian informasi dan disclosure atas aktivitas dan kinerja finansial pemerintah kepada pihak-pihak yang berkepentingan dengan laporan tersebut.

Akuntabilitas diperlukan dalam penyelenggaraan pemerintahan untuk memicu tanggung jawab dari pejabat publik terhadap setiap kebijakan yang diambilnya. Dengan adanya akuntabilitas berdampak pada munculnya kejujuran dan keterukuran kinerja pemerintah sesuai dengan undang-undang dan setiap ketentuan formal yang berlaku. Secara pokok, akuntabilitas adalah kewajiban untuk melaporkan sebuah laporan atau perhitungan sebagai suatu bentuk pertanggungjawaban yang ditujukan kepada pihak yang memberikan tanggung jawab tersebut (Gray \& Jenkins, 1993).

Kebijakan akuntabilitas dalam kaitannya dengan pemberantasan korupsi di Indonesia dimulai sejak dikeluarkannya TAP MPR RI Nomor XI/MPR/1998 dan undang-undang nomor 28 tahun 1999 tentang Penyelenggaraan Negara Yang Bersih dan Bebas dari KKN. Dalam undang-undang nomor 28 tahun 1999 disebutkan bahwa asas penyelenggaraan kepemerintahan yang baik salah satunya adalah asas akuntabilitas. Azas akuntabilitas di sini diartikan bahwa setiap kegiatan dan hasil akhir dari kegiatan penyelenggara negara harus dapat dipertanggungjawabkan kepada masyarakat sebagai pemegang kedaulatan tertinggi negara sesuai dengan ketentuan perundang-undangan yang berlaku.

Dalam rangka menjamin akuntabilitas pemerintah daerah, di Indonesia telah dibuat beberapa peraturan mengenai kewajiban pemerintah daerah dalam menyampaikan akuntabilitasnya secara berkala, yaitu pertama kewajiban untuk menyampaikan akuntabilitas keuangan berupa Laporan Keuangan Pemerintah Daerah (LKPD), kedua kewajiban untuk menyampaikan akuntabilitas kinerja berupa Laporan Akuntabilitas Kinerja Instansi Pemerintah (LAKIP) dan ketiga kewajiban menyampaikan akuntabilitas pelayanan publik melalui Laporan Penyelenggaraan Pemerintahan Daerah (LPPD).

\section{PENGEMBANGAN HIPOTESIS}

\section{Hubungan Akuntabilitas Keuangan dan Persepsi Bersih Korupsi}

BPKP (2001) menjelaskan akuntabilitas keuangan merupakan pertanggungjawaban mengenai integritas keuangan, pengungkapan dan ketaatan terhadap peraturan perundangundangan. Akuntabilitas keuangan menekankan pada pengendalian dan pengawasan dalam penggunaan/alokasi sumber daya publik (input). Pengalokasian sumber daya ini harus sesuai dengan peraturan dan prosedur yang berlaku. Sasarannya adalah laporan keuangan pemerintah yang mencakup penerimaan, penyimpanan dan pengeluaran keuangan instansi pemerintah.

Peraturan Pemerintah Nomor 71 tahun 2010 tentang Standar Akuntansi Pemerintah mengungkapkan penyusunan Laporan keuangan pemerintah bertujuan untuk menyediakan informasi yang relevan mengenai posisi keuangan dan seluruh transaksi yang dilakukan oleh suatu entitas pelaporan selama satu periode pelaporan. Tujuan pelaporan keuangan pemerintah secara spesifik adalah untuk menyajikan informasi yangberguna untuk pengambilan keputusan dan untuk menunjukkan akuntabilitasentitas pelaporan atas sumber daya yang dipercayakan kepadanya. Untuk dapat digunakan sebagai sarana pengambilan keputusan, laporan keuangan harus dapat memberikan informasi mengenai nilai sumber daya ekonomi yang dimanfaatkan untuk melaksanakan kegiatan operasional pemerintahan, menilai 
kondisi keuangan, mengevaluasi efektivitas dan efisiensi suatu entitas pelaporan, dan membantu menentukan ketaatannya terhadap peraturan perundang-undangan.

Penyusunan dan penyajian Laporan Keuangan Pemerintah Daerah (LKPD) dilakukan sesuai dengan peraturan pemerintah yang mengatur tentang standar akuntansi pemerintahan. Laporan Keuangan Pemerintah Daerah (LKPD) disampaikan kepada Badan Pemeriksa Keuangan (BPK) untuk dilakukan pemeriksaan. Pemeriksaan tentang akuntabilitas LKPD dilakukan BPK sebagai pemeriksa pengelolaan dan tanggung jawab tentang keuangan Negara. Pemeriksaan (audit) atas LKPD oleh Badan Pemeriksa Keuangan merupakan salah satu upaya untuk meningkatkan akuntabilitas keuangan pemerintah daerah (Rosalina, 2011).

Beberapa studi telah mengungkapkan pengaruh positif akuntabilitas keuangan terhadap upaya pemberantasan korupsi. Hasil penelitian Olken (2007) menyatakan bahwa dengan adanya penekanan terhadap akuntabilitas pengelolaan dana pembangunan, akan menurunkan tingkat korupsi yang dilakukan oleh pemerintah kecamatan yang mengelola dana tersebut. Penelitian lain diungkapkan oleh Palmer (2000) yang menyatakan pencegahan korupsi dapat dilakukan dengan manajemen pencatatan yang baik dalam rangka mendukung akuntabilitas keuangan. Penelitian lainnya dilakukan oleh Rini \& Sarah (2014), hasil penelitian menunjukkan terdapat kaitan antara kualitas pelaporan keuangan pemerintah daerah dengan tingkat korupsi. Hasil penelitian serupa diungkapkan oleh Masyitoh, et.al. (2015), hasil penelitian menunjukkan akuntabilitas keuangan berpengaruh negatif terhadap korupsi, yaitu berarti semakin baik tata kelola pemerintahan terutama prinsip akuntabilitas dan transparansi dapat menurunkan potensi korupsi.

Berdasarkan penjelasan diatas, maka dapat diajukan hipotesis sebagai berikut:

$\mathbf{H}_{1}$ : Akuntabilitas keuangan berpengaruh positif terhadap persepsi bersih korupsi pemerintah daerah

\section{Hubungan Akuntabilitas Kinerja dan Persepsi Bersih Korupsi}

Institusi pemerintahan umumnya pada satu sisi belum dirumuskan dengan jelas visi dan misi yang diembannya, dan belum dirumuskan tujuan dan sasaran yang harus dicapai dalam periode tertentu guna mencapai visi dan misi tersebut. Akibatnya, terhadap instansi pemerintah sulit dilakukan penilaian apakah instansi tersebut berhasil mencapai sasarannya atau tidak. Akibat lebih lanjut adalah kurangnya perhatian pada efisiensi penggunaan sumber daya yang dimiliki. Keadaan ini memunculkan situasi organisasi yang kondusif untuk praktik korupsi (Peters, 2007).

Melalui Instruksi Presiden (Inpres) nomor 7 Tahun 1999 tentang Akuntabilitas Kinerja Instansi Pemerintah, instansi-instansi pemerintah termasuk pemerintah daerah diwajibkan untuk melaporkan aktivitasnya dalam pelaksanaan pemerintahan. Akuntabilitas kinerja sendiri adalah perwujudan kewajiban suatu instansi pemerintah untuk mempertanggungjawabkan keberhasilan/kegagalan pelaksanaan program dan kegiatan yang telah diamanatkan para pemangku kepentingan dalam rangka mencapai misi organisasi secara terukur dengan sasaran/target kinerja yang telah ditetapkan melalui laporan kinerja instansi pemerintah yang disusun secara periodik. Akuntabilitas kinerja bagi instansi pemerintah sangat diperlukan dalam rangka lebih meningkatkan pelaksanaan pemerintahan yang lebih berdaya guna, berhasil guna, bersih dan bertanggung jawab. Termasuk apakah kinerja pemerintah telah ekonomis, efisien dan efektif dalam pencapaian visi, misi dan tujuan organisasinya. 
Informasi kinerja yang dikandung dalam akuntabilitas kinerja memiliki dua fungsi utama. Pertama, informasi kinerja ini disampaikan kepada publik sebagai bagian dari pertanggungjawaban penerima amanat kepada pemberi amanat. Kedua, informasi kinerja yang dihasilkan dapat digunakan oleh publik maupun penerima amanat untuk memicu perbaikan kinerja pemerintah. Melalui akuntabilitas kinerja akan dapat dinilai kinerja instansi pemerintah baik jangka pendek (tahunan) maupun dalam kaitan tujuan jangka panjangnya. Dengan demikian akan tumbuh suatu kondisi yaitu semua organisasi pemerintah akan berusaha mengurangi penghambat pencapaian kinerja yang salah satunya adalah tindakantindakan korupsi.

Beberapa penelitian terkait hubungan akuntabilitas kinerja dan persepsi bersih korupsi dilakukan oleh Peters (2007) mengungkapkan Akuntabilitas harus dapat memberikan gambaran mengenai program-program yang telah dan akan dilaksanakan oleh pemerintah. Dengan adanya akuntabilitas atas program pemerintah, dapat memberikan gambaran apakah program tersebut telah memberikan manfaat kepada masyarakat, dan jika diketahui bahwa program tersebut ternyata merupakan program yang buruk, maka segera dapat dicari penyebabnya dan dapat diperbaiki. Akuntabilitas atas program pemerintah diyakini lebih dapat mengidentifikasi penyimpangan dan korupsi.Penelitian lain diungkapkan oleh Shah (2007) yang menyatakan korupsi lebih sulit dideteksi melalui audit keuangan, namun korupsi lebih mudah dideteksi melalui pengamatan atas kinerja pelayanan publik.

Berdasarkan penjelasan diatas, maka dapat diajukan hipotesis sebagai berikut:

$\mathbf{H}_{2}$ : Akuntabilitas kinerja berpengaruh positif terhadap persepsi bersih korupsi pemerintah daerah

\section{Hubungan Akuntabilitas Pelayanan Publik dan Persepsi Bersih Korupsi}

Tujuan dari akuntabilitas pelayanan publik adalah untuk mengetahui keberhasilan pemerintah daerah dalam memanfaatkan hak yang diperoleh daerah sesuai dengan capaian keluaran dan hasil yang telah direncanakan, serta sebagai umpan balik dan rekomendasi bagi daerah untuk mendorong peningkatan kinerja penyelenggaraan pemerintah daerah(Afriyanti et al., 2015). Selain itu akuntabilitas pelayanan publik juga dapat dipakai pemerintah pusat untuk mencapai tujuan desentralisasi dan otonomi daerah adalah melakukan proses monitoring dan evaluasi secara teratur dan komprehensif, guna mengukur kemajuan dan tingkat keberhasilan pemerintah daerah dalam penerapan prinsip otonomi daerah dan penyelenggaraan urusan pemerintahan.

Dasar hukum utama kewajiban akuntabilitas pelayanan publik di daerah adalah undang-undang nomor 32 tahun 2004 tentang Pemerintahan Daerah, pada Pasal 27 ayat 2 disebutkan bahwa kepala daerah mempunyai kewajiban juga untuk memberikan laporan penyelenggaraan pemerintahan daerah kepada Pemerintah, dan memberikan laporan keterangan pertanggungjawaban kepada DPRD, serta menginformasikan laporan penyelenggaraan pemerintahan daerah kepada masyarakat. Selanjutnya pemerintah mengeluarkan Peraturan Pemerintah nomor 56 tahun 2001 tentang Pelaporan Penyelenggaraan Pemerintahan Daerah yang diperbarui dengan Peraturan Pemerintah nomor 3 tahun 2007 tentang Laporan Penyelenggaraan Pemerintahan Daerah Kepada Pemerintah, Laporan Keterangan Pertanggungjawaban Kepala Daerah Kepada Dewan Perwakilan Rakyat Daerah, dan Informasi Laporan Penyelenggaraan Pemerintahan Daerah Kepada Masyarakat. 
Mekanisme akuntabilitas sektor publik harus dapat menyediakan umpan balik bagi pemerintah dalam rangka meningkatkan kualitas pelayanan publik. Semua instansi pemerintah diharapkan mampu mengidentifikasi keberhasilan dan kegagalan dalam pelayanan publiknya, sehingga dapat diambil langkah-langkah perbaikan dari hasil identifikasi tersebut (Peters, 2007). Dengan adanya akuntabilitas pelayanan publik di pemerintah daerah, diharapkan pemerintah daerah mampu memperbaiki pelayanannya kepada masyarakat. Tingkat kualitas pelayanan publik yang baik menandakan bahwa tingkat korupsi di instansi pemerintah tersebut rendah (Deininger \& Mpuga, 2005).

Berdasarkan penjelasan diatas, maka dapat diajukan hipotesis sebagai berikut:

$\mathbf{H}_{3}$ : Akuntabilitas pelayanan publik berpengaruh positif terhadap persepsi bersih korupsi pemerintah daerah

\section{METODE PENELITIAN}

Populasi pada penelitian ini adalah seluruh kabupaten dan kota di Indonesia, yaitu sebanyak 508 pemerintah daerah. Pemilihan sampel dalam penelitian ini menggunakan metode pemilihan data bukan acak (non random) dengan teknik purposive sampling. Kriteriakriteria yang digunakan dan jumlah sampel dalam penelitian ini yaitu:

\section{Tabel 1. Sampel Penelitian}

\begin{tabular}{|l|l|r|}
\hline No & \multicolumn{1}{|c|}{ Keterangan } & \multicolumn{1}{|c|}{ Jumlah } \\
\hline 1 & Kabupaten dan kota di Indonesia yang menjadi populasi penelitian & 508 \\
\hline 2 & $\begin{array}{l}\text { Kabupaten dan kota di Indonesia yang tidak memiliki Indeks Integritas } \\
\text { Sektor Publik tahun 2012 dan 2013 yang dikeluarkan oleh KPK }\end{array}$ & $(390)$ \\
\hline 3 & $\begin{array}{l}\text { Kabupaten dan kota di Indonesia yang tidak memiliki LKPD tahun } \\
\text { 2012 dan 2013 yang telah diaudit oleh BPK }\end{array}$ & $(0)$ \\
\hline 4 & $\begin{array}{l}\text { Kabupaten dan kota di Indonesia yang tidak memiliki LAKIP tahun } \\
\text { 2012 dan 2013 yang telah dievaluasi oleh KemenpanRB }\end{array}$ & $(14)$ \\
\hline 5 & $\begin{array}{l}\text { Kabupaten dan kota di Indonesia yang tidak memiliki LPPD tahun } \\
\text { 2012 dan 2013 yang telah dievaluasi oleh Kemendagri }\end{array}$ & $(0)$ \\
\hline \multicolumn{1}{|c|}{ Sampel Data yang Dianalisis } \\
\hline
\end{tabular}

\section{Definisi Operasional Variabel}

Persepsi Bersih Korupsi (Y)

Variabel persepsi bersih korupsi dalam penelitian ini diproksikan dengan Indeks Integritas Sektor Publik yang dikeluarkan oleh Komisi Pemberantasan Korupsi (KPK) melalui survei yang dilakukan di beberapa kabupaten dan kota yang ada di Indonesia. Penggunaan indeks integritas sektor publik sebagai proksi atas variabel persepsi bersih korupsi karena integritas sektor publik berelasi erat dengan potensi korupsi. Daerah dengan integritas sektor publik yang tidak baik cenderung memiliki tingkat korupsi yang tinggi (TII, 2015:20). Dalam penelitian ini, indeks integritas sektor publik yang dikeluarkan oleh KPK menggambarkan persepsi masyarakat atas tingkat korupsi di pemerintah daerahnya. Pemerintah daerah dengan tingkat integritas sektor publik yang tinggi menggambarkan tingkat korupsi yang relatif rendah dan akan menghasilkan persepsi bersih korupsi yang lebih baik. Begitu pula sebaliknya, pemerintah daerah dengan tingkat integritas sektor publik yang rendah menggambarkan tingkat korupsi yang relatif tinggi dan akan menghasilkan persepsi bersih korupsi yang kurang baik. 


\section{Akuntabilitas Keuangan (X1)}

Akuntabilitas keuangan pemerintah daerah dalam penelitian ini akan diproksikan dengan opini audit Badan Pemeriksa Keuangan (BPK) untuk Laporan Keuangan Pemerintah Daerah (LKPD).Opini audit dari BPK dijadikan sebagai proksi dari variabel akuntabilitas keuangan dalam penelitian ini didasarkan pada peran lembaga BPK itu sendiri. BPK memiliki fungsi sebagai lembaga independen yang mengeluarkan opini untuk akuntabilitas publik yang tertuang dalam bentuk pelaksanaan anggaran. Opini BPK merupakan salah satu indikator dari keandalan dan akuntabilitas pelaporan pemerintah terkait dengan aktivitas pengelolaan belanja, pendapatan, dan pembiayaan yang berorientasi pada kepentingan publik.

\section{Akuntabilitas Kinerja (X2)}

Untuk mengetahui sejauh mana instansi pemerintah mengimplementasikan Sistem Akuntabilitas Kinerja Instansi Pemerintah (SAKIP)-nya, serta sekaligus untuk mendorong adanya peningkatan kinerja instansi pemerintah, setiap tahun KemenpanRB bersama BPKP melaksanakan evaluasi atas penerapan SAKIP di pemerintah daerah. Hasil evaluasi tersebut yang dijadikan sebagai proksi dari variabel akuntabilitas kinerja dalam penelitian ini.

\section{Akuntabilitas Pelayanan Publik (X3)}

Untuk menilai tingkat akuntabilitas pelayanan publik di pemerintah daerah, Kementerian Dalam Negeri bersama BPKP melakukan Evaluasi Kinerja Penyelenggaraan Pemerintahan Daerah (EKPPD) secara berkala setiap tahun. Hasil evaluasi tersebut yang dijadikan sebagai proksi dari variabel akuntabilitas pelayanan publik dalam penelitian ini.

\section{ANALISIS HASIL PENELITIAN DAN PEMBAHASAN}

Hipotesis dalam penelitian ini diuji melalui regresi berganda dengan menggunakan one-tail testdan dibantu software SPSS 22 dengan tingkat keyakinan $95 \%$ atau $\alpha=5 \%$ atau 0,05 . Padaone-tail test, suatu hipotesis dapat diterima apabila nilai $\mathrm{t} \geq 1,645$. Hasil pengujian hipotesis dapat dilihat pada tabel berikut ini.

Tabel 2. Hasil Analisis Regresi Berganda

\begin{tabular}{|l|r|}
\hline \multicolumn{1}{|c|}{ Variabel } & Koefisien $\boldsymbol{\beta}$ \\
\hline Konstanta & 5,647 \\
\hline (nilai t) & 19,255 \\
\hline Akuntabilitas Keuangan (X1) & $0,281 * *$ \\
\hline (nilai t) & 2,980 \\
\hline Akuntabilitas Kinerja (X2) & $-0,006$ \\
\hline (nilai t) & $-1,036$ \\
\hline Akuntabilitas Pelayanan Publik (X3) & $0,204 *$ \\
\hline (nilai t) & 2,197 \\
\hline Adjusted ${ }^{2}$ & 0,116 \\
\hline Nilai F & $5,512 * *$ \\
\hline **Signifikan pada level 1\%, *Signifikan pada level 5\%
\end{tabular}

Berdasarkan tabel diatas diketahui bahwa adjusted $\mathrm{R}^{2}$ adalah sebesar 0,116 menunjukkan bahwa 11,6\% tingkat persepsi bersih korupsi mampu dijelaskan oleh variabel akuntabilitas keuangan, akuntabilitas kinerja dan akuntabilitas pelayanan publik. Adapun sisanya sebesar $88,4 \%$ dijelaskan oleh sebab-sebab lain diluar tiga variabel independen yang digunakan dalam penelitian ini. Nilai F menunjukan nilai 5,512 pada tingkat signifikansi dibawah 1\%. Dalam 
arti kata lain, dari hasil uji $\mathrm{F}$ terhadap model regresi dapat dinyatakan bahwa terdapat minimal satu variabel independen yang berpengaruh terhadap variabel dependen.

\section{Pembahasan Hasil Uji Hipotesis Pertama}

Hipotesis pertama $\left(\mathrm{H}_{1}\right)$ menyatakan Akuntabilitas keuangan berpengaruh positif terhadap persepsi bersih korupsi pemerintah daerah. Hasil penelitian menunjukkan hipotesis diterima. Hal ini berarti peningkatan akuntabilitas keuangan pada beberapa pemerintah daerah di Indonesia dapat menurunkan tingkat keterjadian korupsi di daerah tersebut.Hasil penelitian ini konsisten dengan hasil penelitian Olken (2007), Palmer (2000), Rini \& Sarah (2014) dan Masyitoh, et.al. (2015).

Pemerintah daerah dengan tingkat akuntabilitas yang baik, yang ditandai dengan memperoleh opini yang baik, disinyalir pemerintah daerah tersebut telah menyelenggarakan proses pencatatan dan akuntansi pengelolaan dana publik yang memadai (Palmer, 2000; Shah, 2007). Adanya asimetri informasi memberikan kesempatan kepada agentuntuk bertindak oportunis termasuk melakukan korupsi. Selanjutnya, akuntabilitas keuangan ditengarai mampu mereduksi masalah asimetri informasi yang terjadi antara pemerintah pusat dan masyarakat sebagai principal dan pemerintah daerah sebagai agent. Hal ini karena melalui mekanisme akuntabilitas keuangan, pemerintah pusat dan masyarakat akan lebih mudah untuk melakukan pengendalian dan pengawasan dalam penggunaan/alokasi sumber daya keuangan yang telah didelegasikan kepada pemerintah daerah.

\section{Pembahasan Hasil Uji Hipotesis Kedua}

Hipotesis kedua $\left(\mathrm{H}_{2}\right)$ menyatakan Akuntabilitas kinerja berpengaruh positif terhadap persepsi bersih korupsi pemerintah daerah. Hasil penelitian menunjukkan hipotesis ditolak. Hal ini berarti peningkatan akuntabilitas kinerja pada beberapa pemerintah daerah di Indonesia tidak memiliki pengaruh pada tingkat keterjadian korupsi di daerah tersebut.Hasil penelitian ini bertentangan dengan penelitian Peters (2007) mengungkapkan Akuntabilitas harus dapat memberikan gambaran mengenai program-program yang telah dan akan dilaksanakan oleh pemerintah. Dengan adanya akuntabilitas atas program pemerintah, dapat memberikan gambaran apakah program tersebut telah memberikan manfaat kepada masyarakat, dan jika diketahui bahwa program tersebut ternyata merupakan program yang buruk, maka segera dapat dicari penyebabnya dan dapat diperbaiki. Akuntabilitas atas program pemerintah diyakini lebih dapat mengidentifikasi penyimpangan dan korupsi. Penelitian lain diungkapkan oleh Shah (2007) yang menyatakan korupsi lebih sulit dideteksi melalui audit keuangan, namun korupsi lebih mudah dideteksi melalui pengamatan atas kinerja pemerintah.

Laporan Akuntabilitas Kinerja Instansi Pemerintah (LAKIP) yang menjadi sumber informasi atas evaluasi Sistem Akuntabilitas Kinerja Instansi Pemerintah (SAKIP) pada dasarnya harus dapat menggambarkan kinerja instansi pemerintah yang sebenarnya, secara jelas (berdasar data yang tepat dan akurat) dan transparan kepada publik (pemberi amanah), dan pihak-pihak yang berkepentingan, mengenai kemampuan (keberhasilan atau kegagalan) setiap pimpinan instansi pemerintah dalam melaksanakan misi, tugas pokok, fungsi, dan kewenangannya. LAKIP harus memuat informasi yang relevan bagi para pengguna laporan tersebut yaitu para pejabat atau unsur pimpinan eksekutif pemerintah, unsur pengawasan, dan unsur perencanaan sehingga digunakan sebagai umpan balik bagi para penyelenggara pemerintah. 
Dari penjelasan tersebut dapat disimpulkan bahwa informasi kinerja yang dikandung dalam LAKIP memiliki dua fungsi utama. Pertama, informasi kinerja disampaikan kepada publik sebagai bagian dari pertanggungjawaban penerima amanat kepada pemberi amanat. Kedua, informasi kinerja yang dihasilkan dapat digunakan oleh publik maupun penerima amanat untuk memicu perbaikan kinerja pemerintah. Rendahnya signifikansi hubungan antara variabel akuntabilitas kinerja dengan persepsi bersih korupsi disinyalir karena belum terpenuhinya dua fungsi utama LAKIP.

Sebagian besar pemerintah daerah belum taat dalam menyampaikan laporan akuntabilitas kinerjanya secara periodik, sehingga hal tersebut bertentangan dengan fungsi pertama LAKIP yaitu informasi kinerja yang disampaikan kepada publik sebagai bagian dari pertanggungjawaban penerima amanat kepada pemberi amanat. Hal tersebut dapat dilihat dari masih banyaknya pemerintah daerah yang tidak mengirimkan LAKIP-nya untuk dievaluasi oleh Kementerian Pendayagunaan Aparatur Negara dan Reformasi Birokrasi (KemenpanRB) ${ }^{4}$. Pada tahun 2012 dari 508 pemerintah daerah kabupaten/kota di Indonesia, hanya 383 pemerintah daerah kabupaten/kota yang mengirimkan LAKIP-nya tepat waktu untuk dievaluasi. Pada dan tahun 2013, terdapat peningkatan jumlah pemerintah daerah kabupaten/kota yang mengirimkan LAKIP-nya tepat waktu untuk dievaluasi yaitu sebanyak 424 pemerintah.

Fungsi kedua LAKIP sebagai sumber informasi kinerja yang dapat digunakan untuk memicu perbaikan kinerja pemerintah juga belum terpenuhi sampai saat ini. Hal ini dapat dilihat dari tidak adanya reward and pusnishment atas tinggi rendahnya capaian akuntabilitas kinerja instansi pemerintah. Hal tersebut berbeda dengan akuntabilitas keuangan dan akuntabilitas pelayanan publik yang mengatur reward and pusnishment atas pencapaian pemerintah daerah.

Berbeda dengan akuntabilitas keuangan dan akuntabilitas pelayanan publik, hingga saat ini capaian atas tingkat akuntabilitas kinerja pemerintah daerah tidak diatur mengenai penghargaan dan sanksi apapun. Bahkan pemerintah daerah yang terlambat atau tidak menyampaikan akuntabilitas kinerjanya "hanya" mendapatkan sanksi diumumkan pada rakor tingkat kepala daerah ${ }^{5}$. Sanksi tersebut belum menyentuh inti dari laporan akuntabilitas kinerja yaitu informasi kinerja pemerintah daerah. Dari penjelasan tersebut dapat disimpulkan bahwa, sumber informasi kinerja yang terdapat dalam LAKIP selama ini tidak berguna untuk pengambilan keputusan, baik bagi pemerintah pusat, masyarakat maupun pemerintah daerah itu sendiri.

Belum terpenuhinya dua fungsi utama LAKIP yang menyebabkan hubungan yang tidak signifikan antara akuntabilitas dan persepsi bersih korupsi dapat dijelaskan dengan menggunakan Decision-Usefulness Approach. Walaupun pada dasarnya pendekatan tersebut lazim digunakan pada akuntansi keuangan, namun tetap dapat digunakan untuk menjelaskan kebermanfaatan laporan kinerja dalam pengambilan keputusan. Dalam Decision-Usefulness Approach dijelaskan bahwa inti adanya laporan tahunan adalah untuk menyediakan informasi bagi investor dalam pengambilan keputusan (Scott, 2009:12). Hal tersebut sesuai dengan hasil

\footnotetext{
${ }^{4}$ http://www.jpnn.com/news/kinerja-buruk-kada-akan-dipermalukan diakses pada 10 Januari 2017 dengan judul "Kinerja Buruk, Kada akan Dipermalukan"

${ }^{5}$ http://www.jpnn.com/news/kineria-buruk-kada-akan-dipermalukan diakses pada 10 Januari 2017 dengan judul "Kinerja Buruk, Kada akan Dipermalukan"
} 
penelitian Ball \& Brown (1968) yang menunjukkan bahwa laporan keuangan tahunan (dalam hal ini income), digunakan oleh para investor di pasar saham dalam pengambilan keputusan investasinya, sehingga laporan keuangan tahunan perusahaan dapat dikatakan bermanfaat.

Pada sektor pemerintah, terutama di pemerintah daerah, akuntabilitas pemerintah daerah yang diwujudkan dalam laporan tahunan baik yang terkait dengan kinerja finansial dan kinerja non finansial, bukan hanya harus dapat memberikan informasi yang bermanfaat bagi para pengguna eksternal, namun juga harus dapat memberikan informasi yang bermanfaat bagi pengguna internal (Steccolini, 2004). Akuntabilitas kinerja finansial yang tergambar melalui laporan keuangan dan akuntabilitas kinerja non finansial yang tergambar dari laporan kinerja dan pelayanan publik, harus dapat memberikan umpan balik bagi pihak eksternal dan internal pemerintah daerah dalam rangka memperbaiki kinerja pemerintah daerah tersebut. Informasi-informasi yang tersedia dalam laporan tahunan yang dibuat oleh pemerintah daerah harus menyediakan informasi bagi pihak eksternal dan internal seperti masyarakat umum dan pemerintah yang lebih tinggi, sebagai pertimbangan mereka dalam membuat keputusan. Bila tidak ada informasi yang dapat digunakan sebagai pertimbangan dalam pengambilan keputusan, maka dapat dikatakan bahwa laporan-laporan tersebut tidak bermanfaat.

Dalam kaitannya dengan penelitian ini, untuk dapat mengidentifikasi korupsi, akuntabilitas kinerja harus memberikan informasi mengenai capaian atas program-program yang telah dan akan dilaksanakan oleh pemerintah. Namun sesuai fakta yang ada, informasi kinerja dalam Laporan Akuntabilitas Kinerja Instansi Pemerintah (LAKIP) pemerintah daerah tidak memenuhi Decision-Usefulness Approach, sehingga informasi tersebut menjadi tidak bermanfaat karena tidak digunakan untuk pengambilan keputusan, termasuk untuk mengidentifikasi adanya korupsi.

\section{Pembahasan Hasil Uji Hipotesis Ketiga}

Hipotesis ketiga $\left(\mathrm{H}_{3}\right)$ menyatakan akuntabilitas pelayanan publik berpengaruh positif terhadap persepsi bersih korupsi pemerintah daerah. Hasil penelitian menunjukkan hipotesis diterima. Hal ini berarti peningkatan akuntabilitas pelayanan publik pada beberapa pemerintah daerah di Indonesia dapat menurunkan tingkat keterjadian korupsi di daerah tersebut.Hasil penelitian ini konsisten yang dengan yang diungkapkan oleh Shah (2007) yang menyatakan salah satu prioritas yang harus dilakukan dalam memberantas korupsi adalah dengan mengukur kinerja pelayanan publik. Shah (2007) menyatakan setiap upaya dalam rangka memenuhi Standar Pelayanan Minimal yang ditargetkan akan memaksa lembaga-lembaga pemerintah untuk mengatasi penyebab dan konsekuensi dari korupsi. Hasil penelitian lain diungkapkan oleh Deininger \& Mpuga (2005) yang menyatakan tingkat kualitas pelayanan publik yang baik menandakan bahwa tingkat korupsi di instansi pemerintah tersebut rendah.

Tujuan pemerintahan pada hakikatnya adalah memberikan pelayanan kepada masyarakat. Pelayanan oleh pemerintah kepada masyarakat tersebut dimaksudkan untuk menciptakan kondisi yang memungkinkan setiap anggota masyarakat mengembangkan kemampuan dan kreativitasnya demi mencapai tujuan bersama. Untuk mencapai maksud yang diinginkan tersebut, pelayanan publik oleh pemerintah harus terbebas dari praktik-praktik korupsi ${ }^{6}$.

\footnotetext{
${ }^{6}$ http://www.bpkp.go.id/sulut/berita/read/9430/100/Pencegahan-Korupsi-untuk-Mencapai-Pelayanan-Publikyang-Prima.bpkp diakses pada 10 Januari 2017 dengan judul "Pencegahan Korupsi untuk Mencapai Pelayanan Publik yang Prima" 
Dari penjelasan diatas dapat diambil kesimpulan bahwa terdapat hubungan timbal balik antara korupsi dan pelayanan publik, yaitu semakin lazim terjadi korupsi yang dilakukan oleh pemerintah daerah maka semakin buruk tingkat pelayanan publik di daerah tersebut. Begitu pula sebaliknya, semakin baik tingkat pelayanan publik, menandakan tingkat korupsi yang kurang lazim di daerah tersebut. Oleh karena hubungan keduanya bersifat timbal balik, maka perbaikan atas pelayanan publik dipercaya dapat menurunkan tingkat kelaziman korupsi (Deininger \& Mpuga, 2005).

\section{KESIMPULAN DAN KETERBATASAN}

\section{Kesimpulan}

Penelitian ini menguji pengaruh akuntabilitas terhadap persepsi bersih korupsi di pemerintah daerah di Indonesia. Kewajiban pemerintah daerah dalam menyampaikan akuntabilitas sendiri terbagi menjadi tiga bagian sesuai peraturan perundangan yaitu akuntabilitas keuangan, akuntabilitas kinerja dan akuntabilitas pelayanan publik.Berdasarkan hasil penelitian dapat disimpulkan bahwa semakin tinggi akuntabilitas keuangan terbukti secara empiris dapat meningkatkan persepsi bersih korupsi pada pemerintah daerah. Hal tersebut memberikan bukti bahwa pemerintah daerah yang telah menyelenggarakan proses pencatatan dan akuntansi pengelolaan dana publik yang memadai dapat menurunkan tingkat kelaziman korupsi di daerah tersebut. Hasil penelitian ini sejalan dengan penelitian yang dilakukan oleh Olken (2007), Palmer (2000), Rini \& Sarah (2014) dan Masyitoh, et.al. (2015).

Hasil penelitian kedua menunjukkan bahwa semakin tinggi akuntabilitas kinerja tidak terbukti secara empiris dapat meningkatkan persepsi bersih korupsi pada pemerintah daerah. Hasil ini sekaligus memberikan bukti secara empiris bahwa akuntabilitas atas pencapaian program-program yang selama ini disusun oleh pemerintah daerah tidak mampu mereduksi tingkat kelaziman korupsi di pemerintah daerah tersebut.

Tidak mampunya akuntabilitas kinerja dalam mereduksi tingkat kelaziman korupsi di pemerintah daerah seperti yang tergambar dalam hasil penelitian ini kemungkinan disebabkan oleh fungsi utama dari akuntabilitas kinerja yang belum terpenuhi. Laporan akuntabilitas kinerja sebagai bagian dari pertanggungjawaban pemerintah daerah kepada masyarakat dan pemerintah pusat, belum dapat menggambarkan kinerja yang sesungguhnya dari pemerintah daerah tersebut. Selain itu informasi yang terkandung dalam laporan akuntabilitas tersebut juga tidak digunakan oleh para pihak yang berkepentingan, sehingga informasi tersebut menjadi tidak bermanfaat karena tidak digunakan untuk pengambilan keputusan, termasuk untuk mengidentifikasi adanya korupsi.

Hasil penelitian ketiga menunjukkan bahwa semakin tinggi akuntabilitas pelayan publik terbukti secara empiris dapat meningkatkan persepsi bersih korupsi pada pemerintah daerah. Hasil ini sekaligus memberikan bukti secara empiris bahwa akuntabilitas atas kewajiban pemerintah daerah dalam memenuhi hak dan pelayanan dasar bagi masyarakat mampu mereduksi tingkat kelaziman korupsi di pemerintah daerah tersebut. Hasil penelitian ini konsisten yang dengan yang diungkapkan oleh Shah (2007) dan Deininger \& Mpuga (2005).

\section{Keterbatasan}

Keterbatasan penelitian ini adalah keterbukaan terkait informasi sebagai dasar pengukuran akuntabilitas kinerja dan akuntabilitas pelayanan publik tidak secara mudah 
diperoleh. Keterbatasan selanjutnya adalah sumber informasi Indeks Integritas Sektor Publik paling terkini yang didapatkan untuk variabel persepsi bersih korupsi adalah tahun 2012 dan 2013, hal tersebut karena KPK tidak melakukan survei integritas sektor publik di pemerintah daerah pada tahun 2014 sampai dengan 2016.

\section{DAFTAR PUSTAKA}

Afriyanti, D., Sabanu, H. G., \& Noor, F. (2015). Penilaian indeks akuntabilitas instansi pemerintah. Jurnal Tata Kelola \& Akuntabilitas Keuangan Negara, 1(1), 21-42.

Ball, R., \& Brown, P. (1968). An Empirical Evaluation of Accounting Income Numbers. Journal of Accounting Research, 6(2), 159-178.

Bergman, M., \& Lane, J. (1990). Public Policy in A Principal-Agent Framework. Journal of Theoretical Politics, 2(3), 339-352. https://doi.org/10.1177/0951692890002003005

Deininger, K., \& Mpuga, P. (2005). Does greater accountability improve the quality of public service delivery? Evidence from Uganda. World Development, 33(1), 171-191. https://doi.org/10.1016/j.worlddev.2004.09.002

Gailmard, S. (2012). Accountability and Principal-Agent Theory. Oxford Handbook of Accountability, (August), 90-105.

https://doi.org/10.1093/oxfordhb/9780199641253.013.0016

Gray, A., \& Jenkins, B. (1993). Codes of accountability in the new public sector. Accounting, Auditing \& Accountability Journal. https://doi.org/10.1108/09513579310042560

Heriningsih, S., \& Marita. (2013). Pengaruh Opini Audit dan Kinerja Keuangan Pemerintah Daerah terhadap Tingkat Korupsi Pemerintah Daerah (Studi Empiris pada Pemerintah Kabupaten dan Kota di Pulau Jawa). Buletin Ekonomi, 11(1), 1-86. https://doi.org/10.1017/CBO9781107415324.004

Ibietan, J. (2013). Corruption and Public Accountability in the Nigerian Public Sector: Interrogating the Omission. European Journal of Business and Management, 5(15), 4149.

Jensen, C., \& Meckling, H. (1976). Theory of the firm: Managerial behavior, agency costs and ownership structure. Journal of Financial Economics, 3, 305-360.

https://doi.org/doi:10.1016/0304-405X(76)90026-X

Kemendikbud. (2011). Pendidikan Anti Korupsi untuk Perguruan Tinggi. (Y. K. Nanang T. Puspito, Marcella Elwina S., Indah Sri Utari, Ed.). Jakarta: Kementerian Pendidikan dan Kebudayaan RI.

Klitgaard, R. (1998). Membasmi Korupsi. Jakarta: Yayasan Obor Indonesia.

Klitgaard, R., Abaroa, R. M., \& Parris, H. L. (2002). Penuntun Pemberantasan Korupsi Dalam Pemerintahan Daerah. Jakarta: Yayasan Obor Indonesia.

KPK. (2014). Integritas Sektor Publik Indonesia Tahun 2013 (Fakta Korupsi Dalam Layanan Publik). Jakarta: Direktorat Penelitian dan Pengembangan Kedeputian Bidang Pencegahan Komisi emberantasan Korupsi. 
Lane, J.-E. (2005). Public administration and public management: the principal-agent perspective. Public Administration, 85(3), 871-874. https://doi.org/10.1111/j.14679299.2007.00673_7.x

Leruth, L., \& Paul, E. (2007). A Principal-Agent Theory Approach to Public Expenditure Management Systems in Developing Countries. OECD Journal on Budgeting, 7(3), 103131. https://doi.org/10.1787/budget-v7-art16-en

Mardiasmo. (2002). Akuntansi Sektor Publik (Edisi Pert). Yogyakarta: Andi.

Mariana, D., Paskarina, C., \& Nurasa, H. (2010). Reformasi Birokrasi dan Paradigma Baru Administrasi Publik di Indonesia. In revitaslisasi administrasi negara (p. 3). Yogyakarta: graha ilmu.

Masyitoh, R. D., Wardhani, R., \& Setyanigrum, D. (2015). Pengaruh Opini Audit, Temuan Audit, dan Tindak Lanjut Hasil Audit terhadap Persepsi Korupsi pada Pemerintah Daerah Tingkat II Tahun 2008-2010. Seminar Nasional Akuntansi 18 Universitas Sumatera Utara Medan, 1-26.

Mishra, A. (2004). Corruption: a review. Journal of Economic Surveys, 15(1), 71-121. https://doi.org/10.1111/1467-6419.00133

Olken, B. A. (2007). Monitoring Corruption: Evidence from a Field Experiment in Indonesia. Journal of Political Economy, 115(2), 200-249. https://doi.org/10.1086/517935

Palmer, M. (2000). Records management and accountability versus corruption, fraud and maladministration. Records Management Journal, 10(2), 61-72. https://doi.org/10.1108/EUM0000000007256

Peraturan Pemerintah Nomor 71. Standar Akuntasi Pemerintah (2010). Republik Indonesia.

Peters, b. guy. (2007). Performance-Based Accountability. In Anwar (Ed.), Performance accountability and combating corruption (pp. 15-31). Washington DC: The World Bank.

Rini, \& Sarah, A. (2014). Opini Audit Dan Pengungkapan Atas Laporan Keuangan Pemerintah Kabupaten Serta Kaitannya Dengan Korupsi Di Indonesia. Etikonomi, 13(1), 1-20. https://doi.org/http://dx.doi.org/10.15408/etk.v13i1.1875

Rosalina, K. (2011). Faktor-Faktor Yang Mempengaruhi Korupsi Di Tingkat Kabupaten Dan Kota Di Indonesia (Dalam Konteks Anggaran Pendapatan dan Belanja Daerah). Tesis Universitas Brawijaya. Tidak Dipublikasikan.

Scott, W. R. (2009). Financial Accounting Theory. Learning, 546.

Shah, A. (2007). Tailoring the fight against corruption to country circumstances. In Performance accountability and combating corruption (pp. 233-254). Washington DC: The World Bank. https://doi.org/doi:10.1596/978-0-8213-6941-8 
Shleifer, A., \& Vishny, R. W. (1993). Corruption. The Quarterly Journal of Economics, 108(3), 599-617. https://doi.org/10.2307/2118402

Steccolini, I. (2004). Is the Annual Report and accountability medium? An empirical investigation into Italian local governments. Financial Accountability \& Management, 20(August), 327-350. https://doi.org/10.1111/j.0267-4424.2004.00389.x

Svensson, J. (2005). Eight Questions about Corruption. Journal of Economic Perspectives, 19(3), 19-42. https://doi.org/10.1257/089533005774357860

TII. (2015). Survei Persepsi Korupsi 2015. Jakarta: Transparancy International Indonesia. https://doi.org/10.1017/S1368980000000069 